\author{
셀레늄함유 청보리 급여가 육성돈의 생산성 및 혈액성상에 \\ 미치는 영향 \\ 이성훈 ${ }^{1} \cdot$ 조익환 $^{2} \cdot$ 김국원 $^{2} \cdot$ 황보순 $^{2} \cdot$ 한옥규 $^{3} \cdot$ 송태화 $^{3} \cdot$ 박태일 $^{3} \cdot$ 최인배 $^{3}$
}

\title{
Influences of Seleniferous Whole Crop Barley Supplement on Growth Performance and Blood Characteristics in Growing Pigs
}

Sung Hoon Lee ${ }^{1}, \mathrm{Ik}_{\mathrm{H} w a n} \mathrm{Jo}^{2}$, Guk Won Kim², Soon Hwangbo², Ouk Kyu $\mathrm{Han}^{3}$, Tae Hwa Song ${ }^{3}$, Tae II Park ${ }^{3}$ and In Bae Choi ${ }^{3}$

\begin{abstract}
This study was conducted to investigate effects of different levels of seleniferous whole crop barley (WCB) supplementation on performance, and blood characteristics as physiological responses in growing pigs. A total of 20 cross-bred pigs $(($ Landrace $\times$ Yorkshire $) \times$ Duroc $)$ were divided into 4 treatments of 5 pigs each and experimental period lasted for 6 weeks. They were fed diets containing 0.1 (non-seleniferous WCB as controls), $0.2,0.4$, and $0.6 \mathrm{mg} / \mathrm{kg}$ levels of selenium (Se) by supplementing seleniferous WCB, and non-seleniferous or seleniferous WCB was formulated to $5 \%$ level in total ration. The diets were isonitrogenous ( $18 \%$ crude protein) and isocaloric (3,500 kcal $/ \mathrm{kg}$ digestible energy) across treatments.

Increasing levels of seleniferous WCB supplements did not affect feed intake and BW gain, and blood total protein concentration was $(\mathrm{p}<0.05)$ significantly higher for $0.2 \mathrm{mg} / \mathrm{kg}$ Se treatments than for controls. On d 14, blood albumin concentration was higher $(\mathrm{p}<0.05)$ for seleniferous WCB supplemented groups than for control group. Contrarily, blood glucose concentration was tended to be higher for controls than for seleniferous WCB groups. Blood total lipid concentration was significantly $(\mathrm{p}<0.05)$ lowered with increasing levels of seleniferous WCB. Serum glutamic-oxaloacetic transaminase and glutamic-pyruvic transaminase did not have any difference among treatments. It was tended that blood total cholesterol and triglyceride were lowered with increasing levels of seleniferous WCB. Blood Se concentration was significantly $(\mathrm{p}<0.05)$ increased with increasing levels of seleniferous WCB. The results indicate that Se present in seleniferous WCB had favorable effects on blood characteristics and blood Se increased by supplementing seleniferous WCB implies not only a good intestinal absorption of Se present in WCB but also the possibility of Se transfer into tissues.
\end{abstract}

(Key words : Seleniferous whole crop barley, Se transfer, Blood characteristics, Growing pigs)

\footnotetext{
${ }^{1}$ 경상남도 축산진흥연구소(Gyeongsangnamdo Livestock Promotion Research Institute, Sancheong 666-962, Korea)

${ }^{2}$ 대구대학교 동물자원학과 (Department of Animal Resources Science, Daegu University, Gyeongsan 712-714, Korea)

${ }^{3}$ 국립식량과학원 (National Institute of Crop Science, Rural Development Administration, Iksan 570-080, Korea)

Corresponding author:Ik Hwan Jo, Department of Animal Resources Science, Daegu University, Gyeongsan 712-714, Korea. Tel) +82-53-850-6725, Fax) +82-53-850-6729, E-mail: greunld@daegu.ac.kr
} 


\section{I. 서 론}

국내 축산업은 외국과의 FTA 협정 및 사료 값 상승으로 인하여 많은 어려움에 처해 있으 며 이러한 축산농가의 어려움에 대한 대응책의 일환으로, 현재 양돈농가에서는 소비자의 요구 에 맞는 육질이 우수할 뿐만 아니라, 고부가 가치의 기능성 생리활성물질이 강화된 고기생 산에 관심이 증가하고 있다.

셀레늄은 1817년 Berzelius에 의해 자연계에 미량 존재하는 원소중 하나로 오랫동안 독성물 질로 인식되어 왔으나(Wendel, 1989), 동물 세 포질 내에서 항산화적 생리활성작용을 하는 glutathione peroxidase (GSH-Px)의 구성 성분으 로 밝혀진 이후(Rotruck 등, 1973), 생체 내에 서 다양한 면역증강에 따른 기능과 역할이 밝 혀지고 있다 (Arthur 등, 1993).

셀레늄의 항산화 효과(Clark, 1996)는 매우 강력한 것으로 알려져 있으며, 항암 효과 (Raymen, 2000)를 포함한 항질병 효과 (Neve, 1996)에 대한 임상실험이 전 세계적으로 매우 활발하게 이루어지고 있으며, 일부 학자들은 항암효과를 나타내기 위해서는 셀레늄 일일권 장 섭취량 $(\mathrm{RDA})$ 의 10 배 이상을 섭취할 것을 권장하고 있다(El-Bayoumy, 2001). 또한, 셀레 늄은 혈중 콜레스테롤 함량 (Jun and Choi, 2002) 및 특히 LDL-콜레스테롤을 감소시켜 (Stone et al., 1994), 혈중 지질대사에도 긍정적 효과를 미치는 것으로 보고되고 있다.

축산물 내 셀레늄은 인체 내 흡수, 체내 축 적 및 셀레늄 함유 단백질로의 재합성을 위한 이용률이 기타 식물성 식품 및 어류에 비해 우 수하고, 고기, 우유 및 계란 내 셀레늄의 대부 분이 함 황아미노산의 황의 위치에 셀레늄이 치환된 $\mathrm{SeMet}$ 및 $\mathrm{SeCys}$ 의 복합 형태로 존재하 여 체내 축적에 효율적이다 (Finley, 2000).

한편, 가축에 화학적 형태가 다른 셀레늄급 원(유기 및 무기)을 급여하였을 때, 유기셀레늄 이 무기셀레늄 보다 장관 내 흡수 및 축적효율
이 높은 것으로 보고되고 있으며(Ortman과 Pehrson, 1999; Lawler 등, 2004), 무기셀레늄은 반추동물의 경우 반추위내 환원된 환경으로 인 하여 불용성 selenide로 전환되어 거의 흡수되 지 않아 대부분이 분으로 배설되고, 단위동물 에서는 대부분의 셀레늄이 뇨로 배설되어 조직 내 셀레늄이 축적되는데 한계가 있다(Hidiroglou et al., 1968). 이에 따라 셀레늄 강화 축산물을 생산하기 위하여 유기셀레늄을 사용하고 있으 나 유기셀레늄제제는 수입의존도가 높을 뿐만 아니라, 첨가수준이 미량이어서 실제 현장에서 적용 시 과량 급여할 경우 중독의 위험이 따르 고 가격이 비싸 농가에서 사용하기에는 부담스 러운 면이 있다.

따라서 본 연구에서는 농도가 다른 셀레늄강 화 청보리를 육성돈에 급여하여 육성돼지의 사 료섭취량, 증체량, 사료효율 및 혈액성상에 미 치는 영향을 조사하여 육성돈에 대한 셀레늄 급여효과를 구명하기 위해 실시하였다.

\section{ㅍ. 재료 및 방법}

\section{1. 공시축 및 시험설계}

시험에 이용된 공시축은 3원 교잡종 [(Landrace $\times$ Yorkshire) $\times$ Duroc] 육성돈 20 두 (개시체중 27.59 $\pm 0.37 \mathrm{~kg}$, 약 70 일령)를 공시하여 예비기간 10 일, 본시험기간 42일간 시험을 실시하였다. 시험설계 는 청보리 내 셀레늄 농도에 의해 $0.1 \mathrm{ppm}$ (Control), $0.2 \mathrm{ppm}, 0.4 \mathrm{ppm}, 0.6 \mathrm{ppm}$ 으로 4처리를 하여 처리구당 5 마리씩 완전 임의배치 하였다.

\section{2. 청보리의 화학적 조성}

시험에 사용된 두 종류의 청보리 (일반 및 셀 레늄시비)는 황숙기에 총체로 수확하여 일광건 조 후 분쇄하여 각각 원료사료로 사용하였고, 각 청보리의 화학적 조성은 Table 1에 나타난 바와 같다. 
Table 1. Chemical composition of Se-fertilized and non-Se-fertilized whole crop barley

\begin{tabular}{lcc}
\hline & \multicolumn{2}{c}{ Whole crop barley $^{\mathrm{I}}$, sun-cured } \\
\cline { 2 - 3 } & $\begin{array}{c}\text { Non-Se- } \\
\text { fertilized }\end{array}$ & Se-fertilized $^{2)}$ \\
\hline \hline Crude protein, \% & 7.20 & 8.05 \\
Dry matter, \% & 97.10 & 97.20 \\
Crude fiber, \% & 21.31 & 25.20 \\
Ether extract, \% & 3.90 & 3.00 \\
Crude ash, \% & 5.20 & 4.70 \\
Calcium, \% & 0.22 & 0.25 \\
Phosphorus, \% & 0.24 & 0.23 \\
Selenium, mg/kg & 0.08 & 11.89 \\
Lysine, \% & 0.43 & 0.33 \\
\hline
\end{tabular}

${ }^{1)}$ Nitrogen fertilizer for $\mathrm{Se}$ and non-Se-barley was applied in the form of urea at a rate of $150 \mathrm{~kg} \mathrm{~N}$ ha ${ }^{-1}$.

2) Sodium selenate as selenium fertilizer was applied at a defined level.

\section{3. 시험사료 및 사양관리}

시험사료는 조단백질 및 가소화에너지 함량 이 각 $18 \%$ 및 $3,400 \mathrm{kcal} / \mathrm{kg}$ 인 이유, 젖돈사료를 급여하였으며 조성은 Table 2와 같다. 셀레늄 함량이 다른 청보리는 사료급여량의 $5 \%$ 로 제 한 급여하였으며, 물은 자동 급수기를 이용하여 자유롭게 섭취할 수 있도록 하였다. 사료의 섭 취량은 1 일 2회 급여량과 다음날 아침 사료급 여 전 잔여사료를 수거하여 그 차이에 의해 계 산하였고, 체중은 2 주마다 측정하여 증체량을 기록하여 일당증체량을 구하였다. 사료효율과 사료요구율은 전 실험기간동안 사료섭취량과 실험 종료 시의 증체량을 근거로 다음과 같은 식 $($ 사료효율 $=$ 증체량/사료섭취량, 사료요구율 은 $=$ 사료섭취량/증체량)의 식으로 산출하였다.

Table 2. Ingredients and chemical composition of experimental diets

\begin{tabular}{lrrrr}
\hline \multirow{2}{*}{ Item } & \multicolumn{3}{c}{ Dietary $\mathrm{Se}, \mathrm{mg} / \mathrm{kg}$} \\
\cline { 2 - 5 } & 0.1 & 0.2 & \multicolumn{1}{c}{0.4} & 0.6 \\
\hline Corn grain, \% & 63.67 & 63.67 & 63.72 & 63.74 \\
Soybean meal, \% & 27.55 & 27.55 & 27.50 & 27.48 \\
Soybean oil, \% & 1.50 & 1.50 & 1.50 & 1.50 \\
Seleniferous whole crop barley, \% & - & 0.50 & 2.20 & 3.90 \\
Non-seleniferous whole crop barley, \% & 5.00 & 4.50 & 2.80 & 1.10 \\
Monocalcium phosphate, \% & 0.80 & 0.80 & 0.80 & 0.80 \\
Limestone, \% & 0.98 & 0.98 & 0.98 & 0.98 \\
Sodium chloride, \% & 0.30 & 0.30 & 0.30 & 0.30 \\
Vitamin/mineral mixture ${ }^{1)}$ \% & 0.20 & 0.20 & 0.20 & 0.20 \\
Total & 100 & 100 & 100 & 100 \\
\hline Chemical composition ${ }^{2)}$ & & & & \\
Crude protein, \% & 18.00 & 18.00 & 18.00 & 18.00 \\
Crude ash, \% & 2.85 & 2.85 & 2.84 & 2.83 \\
Calcium, \% & 0.62 & 0.62 & 0.62 & 0.62 \\
Phosphorus, \% & 0.54 & 0.54 & 0.54 & 0.54 \\
Selenium, mg/kg & 0.14 & 0.20 & 0.40 & 0.60 \\
Lysine, \% & 0.96 & 0.96 & 0.95 & 0.95 \\
DE, kcal/kg & 3489.61 & 3489.61 & 3489.63 & 3489.64 \\
\hline Vitanimy
\end{tabular}

\footnotetext{
${ }^{1)}$ Vitamin/mineral mixture provided per kilogram of diet: 5,820 IU vitamin A, 582 IU vitamin $\mathrm{D}_{3}, 22$ IU vitamin E, $4.4 \mathrm{mg}$ vitamin $\mathrm{K}, 5.8 \mathrm{mg}$ riboflavin, $3.3 \mathrm{mg}$ pantothenic acid, $34.9 \mathrm{mg}$ niacin, $29 \mu \mathrm{g}$ vitamin $\mathrm{B}_{12}$, $100 \mathrm{mg} \mathrm{Zn}, 50 \mathrm{mg} \mathrm{Fe}, 27 \mathrm{mg} \mathrm{Mn}, 6 \mathrm{mg} \mathrm{Cu}$, and $0.7 \mathrm{mg} \mathrm{I}$.

${ }^{2)}$ Calculated value.
} 


\section{4. 시험사료 및 혈액분석}

혈액은 전두수를 시험 개시 2주 후, 4주 후 및 시험 종료 시에 각각 경정맥에서 vacutainer 로 $10 \mathrm{ml}$ 를 채혈하고 원심분리 하여 $(3,000 \mathrm{rpm} /$ 10 분) 냉동보관 후 분석하였는데, 분석방법은 Total protein은 Colorimetry (Modular PE, Hitachi, Japan), Albumin은 BCG Method(Modular analytics, Roche, Germany), Total lipid는 비색 법 (Photometer, Agilent 8453, Germany), Glucose, SGOT (Serum glutamic-oxaloacetic transaminase) 와 SGPT (Serum glutamic-pyruvic transaminase), Cholesterol, Low-density lipoprotein cholesterol (LDL-cholesterol), Triglyceride는 자동생화학 분 석기 (ADVIA 1650, Bayer, Japan), ImmunoglobulinG (IgG)는 Nephelometry법 (Nephelometer, Dade Behring, Germany), Selenium은 Atomic Absorption Spectrophotometry (AA800, Perkin-Elmer, Germany)에 의하여 실시하였다.

\section{5. 통계분석}

본 실험의 결과는 SAS package program (version 6.12, USA, 2009)의 GLM (general linear model)을 이용하여 분산분석하고, 처리군간 평 균비교는 $\mathrm{LSD}$ 검정으로 분석하고, 처리군의 유의성은 $5 \%(\mathrm{P}<0.05)$ 수준으로 하였다.

\section{III. 결과 및 고찰}

\section{1. 사료섭취량, 증체량 및 사료효율}

농도가 다른 셀레늄 함유 청보리를 육성자돈 에 급여하였을 때, 사료섭취량, 증체량 및 사료 효율은 Table 3 과 같다. 실험시작 후 14일까지 의 사료 섭취량은 $1.41 \sim 1.47 \mathrm{~kg}$, 일당증체량은 $0.65 \sim 0.69 \mathrm{~kg}$ 의 범위로 나타났으며, 28 일의 사 료 섭취량은 $1.70 \sim 1.72 \mathrm{~kg}$, 일당증체량은 0.74 $0.76 \mathrm{~kg}$ 으로 나타났으며 처리구간 유의성은 나
타나지 않았다. 42일의 사료 섭취량은 2.17 $2.21 \mathrm{~kg}$ 으로 차이가 나지 않았고, 일당증체량에 서도 $0.79 \sim 0.81 \mathrm{~kg}$ 범위로 나타났다. 사양시험 42 일간의 사료요구율 및 사료효율은 각각 2.37 2.42와 0.41 0.42로 나타나 셀레늄 함량에 따 른 유의적 차이는 나타나지 않았다.

조사료에는 섬유소 함량이 많아 돼지사료로 써의 이용효율이 낮고, 영양소 이용률 감소 (Dierick et al., 1989), 생산성 저하 (Kass et al., 1980) 등 돼지 사료 이용에 제한이 많은 것으 로 알려져 있다(MAF, 2007), 하지만 유럽에서 는 조사료에 많이 함유된 섬유소 성분이 임신 돈의 포만감을 형성하고(Zoiopoulos et al., 1983), 포유돈에는 변비 방지 효과가 있다고 보 고하였고(Mroz et al., 1986), 국내 연구에서도 청보리 발효사료를 돼지에게 급여 시 소화율을 개선시키며 (Park et al., 2010), 호맥사일리지를 후보돈에게 급여 시 임신율이 향상된다고 보고 하였다 (Cho et al., 2007). 조사료의 높은 섬유소 함량은 돼지 사료의 이용에 제한이 되기도 하지 만 적절한 섬유질 사료 첨가는 생산성 향상에 도움을 주는 것으로 사료된다. 또한, 돼지사료에 조사료 적정 첨가수준은 비육돈의 경우 $3.3 \%$ 수준이라고 보고하여 (Cho et al., 2007), 본 시험 에서 공시축은 육성초기로 성장단계는 다르지만 첨가된 청보리가 $5 \%$ 로 비슷한 수준이었다.

사료 중 셀레늄 농도가 건물섭취량과 증체량 에 미치는 영향은 각 축종별로 다양한 연구결 과가 보고되었는데, 면양에게 유기셀레늄 급여 시험에서는 사료섭취량에 영향을 미치지 못했 고(Rock et al., 2001), 임신우에게 무기 및 유 기셀레늄을 급여 시 건초의 섭취량이 처리구간 차이가 없으며 (Gunter et al., 2003), 육성-비육 돈에서도 셀레늄의 첨가 수준에 의해 사료섭취 량 및 증체에 영향을 미치지 않았다고 보고하 였다 (Mahan et al., 1999). 또한, Awadeh et al. (1998)은 셀레늄이 대사 및 성장에 관계하는 갑상선 호르몬에 대하여 활성형 호르몬으로의 전환을 증가시키나, 증체량에는 영향을 미치지 
Table 3. Growth performances of growing pigs fed diets containing increasing levels of seleniferous whole crop barley

\begin{tabular}{|c|c|c|c|c|c|c|}
\hline \multirow{2}{*}{ Items } & \multicolumn{4}{|c|}{ Dietary $\mathrm{Se}, \mathrm{mg} / \mathrm{kg}$} & \multirow{2}{*}{$\mathrm{SEM}^{1)}$} & \multirow{2}{*}{$\mathrm{P}<$} \\
\hline & 0.1 & 0.2 & 0.4 & 0.6 & & \\
\hline \multicolumn{7}{|l|}{$\overline{\mathrm{d} 14}$} \\
\hline Daily feed intake, $\mathrm{kg}$ & 1.41 & 1.44 & 1.47 & 1.45 & 0.058 & 0.4135 \\
\hline Average daily gain, $\mathrm{kg}$ & 0.65 & 0.69 & 0.68 & 0.68 & 0.138 & 0.9663 \\
\hline Feed intake:gain & 2.19 & 2.23 & 2.21 & 2.26 & 0.521 & 0.9972 \\
\hline Gain:feed intake & 0.46 & 0.48 & 0.46 & 0.47 & 0.087 & 0.9788 \\
\hline \multicolumn{7}{|l|}{ d 28} \\
\hline Daily feed intake, $\mathrm{kg}$ & 1.71 & 1.72 & 1.70 & 1.72 & 0.173 & 0.9964 \\
\hline Average daily gain, $\mathrm{kg}$ & 0.74 & 0.75 & 0.74 & 0.76 & 0.105 & 0.9831 \\
\hline Feed intake:gain & 2.31 & 2.29 & 2.29 & 2.26 & 0.315 & 0.9950 \\
\hline Gain:feed intake & 0.43 & 0.44 & 0.43 & 0.44 & 0.053 & 0.9958 \\
\hline \multicolumn{7}{|l|}{$\mathrm{d} 42$} \\
\hline Daily feed intake, $\mathrm{kg}$ & 2.18 & 2.21 & 2.20 & 2.17 & 0.263 & 0.9937 \\
\hline Average daily gain, $\mathrm{kg}$ & 0.79 & 0.81 & 0.80 & 0.81 & 0.091 & 0.9852 \\
\hline Feed intake:gain & 2.76 & 2.73 & 2.75 & 2.68 & 0.290 & 0.9883 \\
\hline Gain:feed intake & 0.36 & 0.37 & 0.36 & 0.37 & 0.039 & 0.9968 \\
\hline \multicolumn{7}{|l|}{ Overall } \\
\hline Initial body weight, $\mathrm{kg}$ & 27.88 & 27.52 & 27.24 & 27.70 & 1.787 & 0.9490 \\
\hline Final body weight, $\mathrm{kg}$ & 58.40 & 59.03 & 58.25 & 59.18 & 2.620 & 0.9260 \\
\hline Daily feed intake, $\mathrm{kg}$ & 1.77 & 1.79 & 1.79 & 1.78 & 0.363 & 0.9967 \\
\hline Average daily gain, $\mathrm{kg}$ & 0.73 & 0.75 & 0.74 & 0.75 & 0.118 & 0.9418 \\
\hline Feed intake:gain & 2.42 & 2.39 & 2.42 & 2.37 & 0.432 & 0.9993 \\
\hline Gain:feed intake & 0.41 & 0.42 & 0.41 & 0.42 & 0.073 & 0.9784 \\
\hline
\end{tabular}

${ }^{1)}$ Standard error of the mean.

않는다고 보고하여 본 시험의 연구와 유사한 결과를 보여 셀레늄의 급여가 섭취량 및 증체 에는 영향을 미치지 않는 것으로 사료된다.

\section{2. 혈액성상}

수준이 다른 셀레늄 함유 청보리를 육성돈에 급여하였을 때, 혈중 총단백질, 알부민, 포도당 및 총지질 농도에 미치는 영항은 Table 4와 같다.

혈중 총단백질 농도는 셀레늄 $0.2 \mathrm{ppm}$ 급여 구가 3 6주에 각각 7.18 과 $7.64 \mathrm{~g} / \mathrm{dl}$ 으로 대조구 및 다른 처리구에 비하여 유의하게 높게 나타 났다 $(\mathrm{p}<0.05)$. 혈중 알부민농도는 0 2주차 셀레 늄 급여시험구가 $3.56 \sim 3.92 \mathrm{~g} / \mathrm{dl}$ 으로 대조구의 $3.14 \mathrm{~g} / \mathrm{dl}$ 보다 유의하게 높게 나타났으며 $(\mathrm{p}<$
$0.05)$, 시험 전기간에는 $0.4 \mathrm{ppm}$ 급여구가 3.76 $\mathrm{g} / \mathrm{dl}$ 으로 대조구 보다 유의하게 높게 나타났다 $(\mathrm{p}<0.05)$. 혈중 글루코스 함량은 대조구가 높은 경향으로 나타났는데 특히 28일에는 $101.6 \mathrm{mg} /$ $\mathrm{dl}$ 으로 가장 높았다 $(\mathrm{p}<0.05)$. 혈중 총지질 농도 는 셀레늄 농도가 높을수록 유의하게 낮아져 0.4 와 $0.6 \mathrm{ppm}$ 급여구가 각각 267 과 $264 \mathrm{mg} / \mathrm{dl}$ 으로 대조구의 $304 \mathrm{mg} / \mathrm{dl}$ 보다 유의하게 낮았 다 $(\mathrm{p}<0.05)$.

셀레늄의 체내 약리작용 중 항산화 (Clark, 1996) 및 항질병 (Neve, 1996) 효과에 대해서는 널리 알려진 바이다. 자돈의 혈액 내 albumin 함량은 면역기능을 나타내는 지표로써, 본 시 험에서는 대조구에 비해 셀레늄 급여 시험구가 유의하게 높게 나타나 특히 어린 (14일차) 성장 
Table 4. Serum metabolic substances of growing pigs fed diets containing increasing levels of seleniferous whole crop barley

\begin{tabular}{|c|c|c|c|c|c|c|}
\hline \multirow{2}{*}{ Items } & \multicolumn{4}{|c|}{ Dietary $\mathrm{Se}, \mathrm{mg} / \mathrm{kg}$} & \multirow{2}{*}{$\mathrm{SEM}^{1)}$} & \multirow{2}{*}{$\mathrm{P}<$} \\
\hline & 0.1 & 0.2 & 0.4 & 0.6 & & \\
\hline \multicolumn{7}{|c|}{ Total protein, $\mathrm{g} / \mathrm{dl}$} \\
\hline d 14 & 6.56 & 6.42 & 6.34 & 6.34 & 0.447 & 0.8469 \\
\hline d 28 & $6.58^{\mathrm{b}}$ & $7.18^{\mathrm{a}}$ & $6.44^{\mathrm{b}}$ & $6.58^{\mathrm{b}}$ & 0.351 & 0.0193 \\
\hline d 42 & $6.94^{\mathrm{b}}$ & $7.64^{\mathrm{a}}$ & $7.02^{\mathrm{b}}$ & $7.00^{\mathrm{b}}$ & 0.373 & 0.0296 \\
\hline Overall & $6.69^{\mathrm{b}}$ & $7.08^{\mathrm{a}}$ & $6.60^{\mathrm{b}}$ & $6.64^{\mathrm{b}}$ & 0.502 & 0.0425 \\
\hline \multicolumn{7}{|c|}{ Albumin, $\mathrm{g} / \mathrm{dl}$} \\
\hline d 14 & $3.14^{\mathrm{b}}$ & $3.60^{\mathrm{a}}$ & $3.92^{\mathrm{a}}$ & $3.56^{\mathrm{a}}$ & 0.297 & 0.0070 \\
\hline d 28 & 3.46 & 3.46 & 3.62 & 3.28 & 0.252 & 0.2491 \\
\hline d 42 & 3.70 & 3.68 & 3.74 & 3.68 & 0.192 & 0.9537 \\
\hline Overall & $3.43^{\mathrm{b}}$ & $3.58^{\mathrm{ab}}$ & $3.76^{\mathrm{a}}$ & $3.51^{b}$ & 0.286 & 0.0189 \\
\hline \multicolumn{7}{|c|}{ Glucose, $\mathrm{mg} / \mathrm{dl}$} \\
\hline d 14 & 101.60 & 89.40 & 81.40 & 97.40 & 14.46 & 0.1688 \\
\hline d 28 & $101.60^{\mathrm{a}}$ & $76.80^{\mathrm{b}}$ & $80.00^{\mathrm{b}}$ & $81.60^{\mathrm{b}}$ & 10.98 & 0.0209 \\
\hline d 42 & 93.00 & 80.80 & 89.80 & 82.20 & 11.16 & 0.2814 \\
\hline Overall & $98.73^{\mathrm{a}}$ & $82.33^{\mathrm{b}}$ & $87.07^{b}$ & $90.40^{\mathrm{ab}}$ & 12.50 & 0.0062 \\
\hline \multicolumn{7}{|c|}{ Total lipid, $\mathrm{mg} / \mathrm{dl}$} \\
\hline d 14 & 292.2 & 268.4 & 285.8 & 262.2 & 28.54 & 0.3312 \\
\hline d 28 & 318.2 & 282.4 & 257.8 & 274.8 & 55.37 & 0.3956 \\
\hline d 42 & 304.4 & 308.0 & 258.8 & 256.8 & 39.84 & 0.0995 \\
\hline Overall & $304.9^{\mathrm{a}}$ & $286.2^{\mathrm{ab}}$ & $267.4^{\mathrm{b}}$ & $264.6^{\mathrm{b}}$ & 41.53 & 0.0359 \\
\hline
\end{tabular}

1) Standard error of the mean.

${ }^{\mathrm{a}, \mathrm{b}}$ Means in a row with different superscripts are significantly different $(\mathrm{p}<0.05)$.

단계에서 면역 기능의 효과가 있음을 알 수 있 었다. 하지만 혈중 $\operatorname{IgG}$ (Table 6)에서는 유의적 인 차이가 나타나지 않아 추후 체계적인 조사 가 필요할 것으로 사료된다.

일반적으로 혈중 glucose는 탄수화물의 최종 산물로서 체조직에 에너지를 공급하는 역할을 하며, 혈중 glucose의 수준은 insulin의 동화작 용과 glucagon, catecholamin과 glucocoticoids의 이화작용에 의하여 변화하는데 insulin과 glucagon 은 서로 길항작용을 하며(Smith, 1989), 혈중 glucose의 증가는 간에서 당생산이 증가하고 있 음을 의미하며, glucose의 감소는 지방 분해로 glucose 이용이 감소되기 때문인 것으로 알려져 있다(Brockman과 Berbman, 1975). 본 시험에서 는 셀레늄을 급여하지 않은 대조구가 당생산이 증가하고, 한편으로 셀레늄 급여구는 지방 분
해로 인해 총지질 함량 및 glucose 이용이 감소 됨을 알 수 있었다.

다양한 배합수준의 셀레늄 함유 청보리 사료 를 육성돈에 급여하였을 때, 간기능효소 (SGOT, $\mathrm{SGPT}$, 콜레스테롤 및 중성지방에 미치는 영향 은 Table 5 와 같다.

SGOT 및 SGPT는 주별로 유의한 차이는 없 었으나 점차 감소되는 경향이었고, 대조구와 셀레늄함유 청보리 급여구 간에도 차이는 나타 나지 않았다. 혈중 총콜레스테롤은 28 일 및 42 일에 대조구가 각각 100.2 와 $112 \mathrm{mg} / \mathrm{dl}$ 으로 셀 레늄 시험구의 각각 $84.6 \sim 90.8$ 과 $95 \sim 106.6 \mathrm{mg} / \mathrm{dl}$ 보다 높은 경향으로 나타나 셀레늄 급여로 총 콜레스테롤이 낮아졌다. 혈중 중성지방은 대조 구가 $66.73 \mathrm{mg} / \mathrm{dl}$ 으로 셀레늄 시험구의 52.87 $56.27 \mathrm{mg} / \mathrm{dl}$ 보다 높은 경향이었다. 
Table 5. Hepatic lesion enzymes and lipid metabolic intermediates in the serum of growing pigs fed diets containing increasing levels of seleniferous whole crop barley

\begin{tabular}{|c|c|c|c|c|c|c|}
\hline \multirow{2}{*}{ Item } & \multicolumn{4}{|c|}{ Dietary $\mathrm{Se}, \mathrm{mg} / \mathrm{kg}$} & \multirow{2}{*}{$\mathrm{SEM}^{4)}$} & \multirow{2}{*}{$\mathrm{P}<$} \\
\hline & 0.1 & 0.2 & 0.4 & 0.6 & & \\
\hline \multicolumn{7}{|c|}{$\overline{\text { SGOT }^{1)}, \mathrm{U} / \ell}$} \\
\hline d 14 & 74.60 & 57.80 & 71.20 & 71.60 & 23.054 & 0.6697 \\
\hline d 28 & 59.60 & 46.60 & 50.40 & 49.00 & 11.983 & 0.3680 \\
\hline d 42 & 48.80 & 46.60 & 41.00 & 43.00 & 20.066 & 0.9264 \\
\hline Overall & 61.00 & 50.33 & 54.20 & 54.53 & 20.703 & 0.5656 \\
\hline \multicolumn{7}{|c|}{$\mathrm{SGPT}^{2)}, \mathrm{U} / \ell$} \\
\hline d 14 & 53.40 & 42.00 & 69.80 & 53.40 & 14.725 & 0.0606 \\
\hline d 28 & 56.20 & 42.80 & 43.20 & 46.00 & 8.987 & 0.1031 \\
\hline d 42 & 47.00 & 38.80 & 35.80 & 43.40 & 13.553 & 0.5851 \\
\hline Overall & 52.20 & 41.20 & 49.60 & 47.60 & 14.289 & 0.1952 \\
\hline \multicolumn{7}{|c|}{ Total cholesterol, $\mathrm{mg} / \mathrm{dl}$} \\
\hline d 14 & 94.40 & 95.60 & 101.80 & 95.20 & 11.281 & 0.7173 \\
\hline d 28 & 100.20 & 89.20 & 90.80 & 84.60 & 10.104 & 0.1403 \\
\hline d 42 & 112.00 & 106.60 & 95.00 & 100.80 & 14.177 & 0.2971 \\
\hline Overall & 102.20 & 97.13 & 95.87 & 93.53 & 12.990 & 0.3212 \\
\hline \multicolumn{7}{|c|}{ LDL cholesterol $^{3)}, \mathrm{mg} / \mathrm{dl}$} \\
\hline d 14 & 49.40 & 52.40 & 49.00 & 51.40 & 9.211 & 0.9252 \\
\hline d 28 & 49.60 & 49.40 & 48.80 & 44.00 & 5.880 & 0.4100 \\
\hline d 42 & 55.80 & 54.40 & 44.20 & 46.60 & 12.201 & 0.3792 \\
\hline Overall & 51.60 & 52.07 & 47.33 & 47.33 & 9.164 & 0.3138 \\
\hline \multicolumn{7}{|c|}{ Triglyceride, $\mathrm{mg} / \mathrm{dl}$} \\
\hline d 14 & 61.20 & 57.60 & 53.00 & 57.20 & 13.395 & 0.8151 \\
\hline d 28 & 69.80 & 43.20 & 58.40 & 57.60 & 15.199 & 0.0904 \\
\hline d 42 & 69.20 & 57.80 & 57.40 & 52.60 & 16.889 & 0.4774 \\
\hline Overall & 66.73 & 52.87 & 56.27 & 55.80 & 14.773 & 0.0664 \\
\hline
\end{tabular}

셀레늄은 항산화 및 면역증강 효과 등 인체 에 유익한 필수미량원소이나 한편으로 독성을 나타내는 물질로 알려져 왔다(Wendel, 1989). 셀레늄의 독성과 관련된 표적 장기는 간으로 (Jia 등, 2005) 혈중 SGOT 및 SGPT는 간기능 이상의 주된 지표이다. 도 등 (1990)은 경상북 도에서 도축되는 돼지 98 두의 $\mathrm{SGOT}$ 와 $\mathrm{SGPT}$ 를 조사 시 각각 $43.9 \pm 10.8 \sim 58.6 \pm 10.6$ 와 $38.6 \pm$ 5.3 40.5 $4.6 \mathrm{U} / \ell$ 로 보고하여 본 시험과 비슷 한 결과를 보였으며, 대조구와 셀레늄 시험구
간 차이가 나타나지 않아 독성수준은 아닌 것 으로 판단되며, Kim과 Mahan (2001)은 돼지사 료에 셀레늄 독성이 나타나는 수준은 $5 \mathrm{ppm}$ 이 상이라고 보고하여 본 시험에서 급여한 셀레늄 수준은 셀레늄 독성을 나타내기에는 낮은 수준 으로 사료된다.

셀레늄의 체내 중요한 기능은 적혈구 안에 있는 glutathione peroxidase (GSH-Px)의 구성 성 분으로 적혈구의 막과 세포막을 과산화물로부 터 보호해 주는 역할을 함으로(Rotruck et al., 
Table 6. Serum IgG and Se concentrations of growing pigs fed diets containing increasing levels of seleniferous whole-crop barley

\begin{tabular}{|c|c|c|c|c|c|c|}
\hline \multirow{2}{*}{ Item } & \multicolumn{4}{|c|}{ Dietary $\mathrm{Se}, \mathrm{mg} / \mathrm{kg}$} & \multirow{2}{*}{$\mathrm{SEM}^{1)}$} & \multirow{2}{*}{$\mathrm{P}<$} \\
\hline & 0.1 & 0.2 & 0.4 & 0.6 & & \\
\hline \multicolumn{7}{|c|}{$\mathrm{IgG}, \mathrm{mg} / \mathrm{dl}$} \\
\hline d 14 & 989.6 & 857.8 & 923.0 & 871.2 & 137.54 & 0.5428 \\
\hline d 28 & 949.2 & 948.8 & 953.0 & 906.8 & 186.29 & 0.5247 \\
\hline d 42 & 818.6 & 929.2 & 901.2 & 857.0 & 102.21 & 0.5170 \\
\hline Overall & 919.1 & 911.9 & 925.7 & 878.3 & 200.51 & 0.6215 \\
\hline \multicolumn{7}{|c|}{ Selenium, $\mu \mathrm{g} / \mathrm{ml}$} \\
\hline d 14 & $189.4^{\mathrm{c}}$ & $201.8^{\mathrm{c}}$ & $318.8^{\mathrm{b}}$ & $385.4^{\mathrm{a}}$ & 37.279 & $<0.0001$ \\
\hline d 28 & $191.0^{\mathrm{c}}$ & $230.8^{\mathrm{c}}$ & $359.6^{\mathrm{b}}$ & $486.8^{\mathrm{a}}$ & 59.049 & $<0.0001$ \\
\hline d 42 & $190.6^{\mathrm{c}}$ & $244.0^{\mathrm{c}}$ & $363.2^{\mathrm{b}}$ & $497.6^{\mathrm{a}}$ & 34.010 & $<0.0001$ \\
\hline Overall & $190.1^{\mathrm{c}}$ & $225.5^{\mathrm{c}}$ & $347.1^{\mathrm{b}}$ & $456.6^{\mathrm{a}}$ & 50.983 & $<0.0001$ \\
\hline
\end{tabular}

1) Standard error of the mean

${ }^{a}, b, c$ Means in a row with different superscripts are significantly different $(p<0.05)$.

1973), 지방 과산화물의 생성을 억제 하거나 콜레 스테롤 대사의 변화를 가져와 체내 지질에 직접 적인 영향을 미친다(Salonen et al., 1991). 본 시 험에서도 혈중 총콜레스테롤 및 총지질(Table 4) 의 함량이 셀레늄 첨가로 감소하는 경향으로 나 타났는데, Stone et al.(1994)은 흰쥐에게 셀레늄 을 공급하였을 때 LDL-콜레스테롤의 감소로 인 해 총콜레스테롤이 감소하며, Jun과 Choi (2002)는 셀레늄을 공급 시 콜레스테롤 함량이 낮아졌다고 보고하여 본 시험과 비슷한 결과를 보여, 셀레늄 공급이 총지질과 LDL-콜레스테롤 감소와 같이 지 질대사를 개선하는 것으로 사료된다.

다양한 배합수준의 셀레늄 함유 청보리 사료를 육성돈에 급여하였을 때, 혈중 면역글로불린 및 셀레늄 농도에 미치는 영향은 Table 6과 같다.

혈중 면역글로불린은 셀레늄 함유 청보리 급 여로 시험구간 차이가 나타나지 않았다. 하지 만 혈중 셀레늄 농도는 대조구가 $190.1 \mu \mathrm{g} / \mathrm{ml}$, $0.2 \mathrm{ppm}$ 구가 $225.5 \mu \mathrm{g} / \mathrm{ml}, \quad 0.4 \mathrm{ppm}$ 구가 $347.1 \mu \mathrm{g}$ $/ \mathrm{ml}, 0.6 \mathrm{ppm}$ 구가 $456.6 \mu \mathrm{g} / \mathrm{ml}$ 으로 고농도의 셀 레늄을 함유한 시험구일수록 유의적으로 높아 졌다 $(\mathrm{p}<0.05)$.

본 시험에서 혈중 셀레늄 농도는 $\mathrm{ml}$ 당 190.1 $\mu \mathrm{g}$ 이상으로 나타났고, Puls (1989)가 제시한 동
물체내 최적의 GSH-Px 활성과 면역기능에 필 요로 하는 최저 셀레늄 수준이 $\quad 60 ~ 150 \mu \mathrm{g} / \mathrm{ml}$ 이라 보고하여 본 시험에 이용된 자돈에서는 셀레늄 부족현상이 나타나지 않았다. 또한 청 보리에 존재하는 셀레늄은 장관 내 흡수율뿐만 아니라 축적율이 높은 유기셀레늄이 대부분으 로, 혈액 내 셀레늄 농도가 증가하는 것을 감 안한다면, 청보리 내 셀레늄은 장관 내 흡수율 이 우수한 것으로 사료된다. Gunter et al. (2003) 은 유-무기셀레늄 모두는 장관 내 흡수가 잘 된다고 보고하였고, 증가하는 수준은 무기셀레 늄보다는 유기셀레늄이 혈중 셀레늄 농도가 더 욱 높은 것으로 보고하였다.

일반적으로 조직 내 셀레늄 함량은 혈중 셀 레늄 농도와 밀접한 상관관계를 가지는 것으로 알려져 있고(Hintze et al., 2001), 본 연구의 혈 중 셀레늄 농도결과를 비추어 보면, 혈중 순환 되는 셀레늄이 조직으로 운반되어 축적될 것으 로 기대된다.

IV. 요 약

본 연구는 다양한 배합수준의 셀레늄 함유 청보리 사료를 육성돈에 급여 시 육성돈의 성 
장특성 및 혈액성상에 미치는 영향을 조사하였 다. 시험은 육성돈 20 두를 공시하였고, 처리구 는 셀레늄수준에 따라 4 처리구 $(0.1 \mathrm{ppm}$ (대조 구), $0.2 \mathrm{ppm}, 0.4 \mathrm{ppm}, 0.6 \mathrm{ppm}$ )로 나누어 처리 구당 5 두씩 배치하여, 6주간 사양시험을 실시 하였다. 각 시험사료는 셀레늄 함유 및 일반 청보리를 조합하여 배합비의 $5 \%$ 를 첨가하였고, 조단백질 및 대사에너지 함량은 각 $18 \%$ 및 $3,500 \mathrm{kcal} / \mathrm{kg}$ 을 함유하도록 배합하였다.

실험 사료 내에 셀레늄의 함유 수준을 증가 하였을 때 사료섭취량과 증체에 영향을 미치지 않았고, 혈중 총단백질 농도는 $0.2 \mathrm{ppm}$ 급여구 가 대조구보다 유의하게 높았다 $(\mathrm{p}<0.05)$. 사양 연구 14 일에 혈중 알부민농도는 셀레늄 함유 청보리 급여구가 대조구보다 유의하게 높았다 $(\mathrm{p}<0.05)$. 혈중 포도당 농도는 대조구가 셀레늄 함유 청보리 급여구보다 높은 경향이었다. 혈 중 총지질 농도는 사료 내 셀레늄 함량이 증가 함에 따라 유의하게 낮았다 $(\mathrm{p}<0.05)$. SGOT 및 $\mathrm{SGPT}$ 는 대조구와 셀레늄 함유 청보리 급여구 간에 차이가 없었다. 혈중 총콜레스테롤과 중 성지방은 셀레늄 청보리 급여로 낮아지는 경향 이었다. 혈중 셀레늄 농도는 셀레늄 함유 청보 리 급여수준이 증가함에 따라 유의하게 증가하 였다 $(\mathrm{p}<0.05)$. 이상의 결과에서 청보리 내 존재 하는 셀레늄은 육성돈의 혈액성상을 개선시키 고, 셀레늄 함유 청보리의 급여로 증가된 혈중 셀레늄 농도는 돼지 장관 내 청보리 내 셀레늄 이용효율이 우수할 뿐만 아니라 조직 내 셀레 늄 전이 가능성을 시사한다.

$$
\mathrm{V} \text {. 사 사 }
$$

본 연구는 농촌진흥청 공동연구사업 수행결 과의 일부로 연구비 지원에 감사드립니다.

\section{VI. 인 용 문 헌}

1. Arthur, J.R., F. Nicol and G.J. Beckett. 1993. Selenium deficiency, thyroid hormone metabolism, and thyroid hormone deiodinases. Am. J. Clin. Nutr. 57:236-239.

2. Awadeh, F.T., R.L. Kincaid and K.A. Johnson. 1998. Effect fo level and source of dietary selenium on concentrations of thyroid hormones and immunoglobulins in beef cows and calves. J. Anim. Sci. 76:1204-1215.

3. Brockman, R. and E.N. Bergman. 1975. Effect of glucagon on plasma alanine and glutamine metabolism and gepatic gouconeogenesis in sheep. Am. J. Physiol. 228:1327.

4. Cho, J.H., Y.K. Han, Y.J. Chen, J.S. Yoo, J.W. Kim and I.H. Kim. 2007. Effects of Feeding Rye Silage on Growth Performance, Blood, and Carcass Characteristics in Finishing Pigs. Korean J. Food Sci. Ani. Resour. 27:235-243.

5. Clark, L.C., G.F. Jr, Combs, B.W. Turnbull, E.H. Slate, D.K. Chalker, J. Chow, L.S. Davis, R.A. Glover, G.F. Graham, E.G. Gross, A. Krongrad, J.L. Jr, A., Lesher, H.K. Park, B.B. Jr, Sanders, C.L. Smith and J.R. Taylor. 1996. Effects of selenium supplementation for cancer prevention in patients with carcinoma of the skin. JAMA. 276: 1957-1963.

6. Dierick, N.A., I.J. Vervaeke, D.I. Demeyera and J.A. Decuyperea. 1989. Approach to the energetic importance of fibre digestion in pigs. I. Importance of fermentation in the overall energy supply. Anim. Feed Sci. Technol. 23:141-167.

7. Do, J.C., C.W. Lee, J.K. Son and J.S. Chung. 1990. Studies on the blood chemistry of Korean native cattle and pigs. Korean, J. Vet. Serv. 13(1): 49-53.

8. El-Bayoumy, K. 2001. The protective role of selenium on genetic damage and on cancer Review Article Mutation Research/Fundamental and Molecular Mechanisms of Mutagenesis, 475:123-139.

9. Finley, J.W. 2000. Does selenium accumulation in meat confer a health benefit to the consumer ? Proc. Soc. Anim. Sci. p1-10.

10. Gunter, S.A., P.A. Beck and J.M. Philips. 2003. Effects of supplementary selenium source on the performance and blood measurements in beef cows and their calves. J. Anim. Sci. 81:856-864.

11. Hidiroglou, M.D., P. Heanley and K.J. Jenkins. 1968. Metabolism of inorganic selenium in rumen 
bacteria. Can. J. Physiol. Pharm. 46: 229-232.

12. Hintze, K.J. G.P. Lardy, M.J. Marchello and J.W. Finley. 2001. Areas with high concentrations of selenium in the soil and forage produce beef with enhanced concentrations of selenium. J. Agric. Food Chem. 49:1062-1067.

13. Jia, X., N. Li and J. Chen. 2005. A subchronic toxicity study of elemental Nano-Se in SpragueDawley rats. Life Sci. 76:1989-2003.

14. Jun, Y.S. and M.K. Choi. 2002. Effect of copper and selenium supplementation on lipid contents in rats. J. East Asian Soc. Dietary Life. 12(2):100106.

15. Kass, M.L., P.J. Van Soest and W.G. Pond. 1980. Utilization of dietary fiber from alfalfa by growing swine. $\Pi$. Volatile fatty acid concentrations in and disappearance from the gastrointestinal tract. J. Anim. Sci. 50:192-197.

16. Kim, Y.Y. and D.C. Mahan. 2001. Comparative effects of high dietary levels of organic and inorganic selenium on selenium toxicity of growing-finishing pigs. J. Anim. Sci. 79:942-948.

17. Lawler, T.L., J.B. Taylor, J.W. Finley and J.s. Caton. 2004. Effect of supranutritional and organically bound selenium on performance, carcass characteristics, and selenium distribution in finishing beef streers. J. Anim. Sci. 82: 1488-1493.

18. MAF, National Institue of Animal Science. 2007. Korean Feeding Standard for Swine. Sangroksa.

19. Mahan, D.C, T.R. Cline and B. Richert. 1999. Effects of dietary levels of selenium-enriched yeast and sodium selenite as selenium sources fed to growing-finishing pigs on performance, tissue selenium, serum glutathione peroxidase activity, carcass characteristics and loin quality. J Anim Sci 77:2172-2179.

20. Mroz, Z., G. Partridge, G. Mitchell and H.D. Keal. 1986. The effects fo oat hulls added to the basal ration for pregnant sows on reproductive performance, apparent digestibiliy, rate of passage and plasma parameters. J. Sci. Food Agric. 37: 239-247.

21. Neve, J. 1996. Selenium as a risk factor for cardiovascular diseases. J. Cardiovasc. Risk 3:4247.
22. Ortman, K. and B. Pehrson. 1999. Effect of selenate as a feed supplement to dairy cows in comparison to selenite and selenium yeast. J. Anim. Sci. 77:3365-3370.

23. Park, D.Y., J.K. Park, S.B. Cho and C.H. Kim. 2010. Effects of dried whole crop barley treated with cellulolytic microorganisms on In vitro fermentation characteristics in swine. J. Kor. Grassl. Forage Sci. 30(2):179-190.

24. Puls, R. 1989. Mineral levels in animal health: Diagnostic data. Sherpa Int., Clearbrook, British Columbia, Canada.

25. Raymen, M.P. 2000. The importance of selenium to human health. The Lancet 356:233-241.

26. Rock, M.J., R.L. Kincaid and G.E. Carstens. 2001. Effects of prenatal source and level of dietary selenium on passive immunity and thermometabolism of newborn lambs. Small Ruminant Res. 40:129-138.

27. Rotruck, J.T., A.L. Pope, H.F. Grather, D.G. Hafeman, A.B. Swanson and W.G. Hoekstra. 1973. Selenium: Biochemical role as a component of glutathione peroxidase. Sci. 179:588-590.

28. Salonen, J.T., R. Salonen, K. Seppanen, M. Kantola, S. Suntionen and H. Korpela. 1991. Interaction of serum copper, selenium and low density lipoprotein cholesterol in atherogenesis, $\mathrm{Br}$. Med. J., 302:756.

29. Smith, R.H. 1989. Nitrogen metabolism in the ruminants stomach. In protein metabolism in farm animals (Bock, H. D., Eggum, B. O., Low, A. G., Simon, O. \& Zebrowska, E. D. S.). Oxford University Press., Oxpord. p.165.

30. Stone, W.L., R.L. Scott, E.M. Stewart and A. Kheshti. 1994. Lipoprotein alterations in the spontaneously hypertensive rat fed diets deficient in selenium and vitamin E, P. S. E. B. M. 206:130.

31. Wendel A. 1989. Selenium in Biology and Medicine. Springer-Verlag, Berlin. pp3-325.

32. Zoiopoulos, P.E., P.R. English and J.H. Topps. 1983. A note on intake and digestibiliy of a fibrous diet self fed to primiparous sows. Anim. Prod. J. Agric. Sci. 37:153-156.

(Received January 2, 2012/Accepted February 29, 2012) 